\title{
IMPLEMENTASI PEMAHAMAN LINTAS BUDAYA DALAM PEMBELAJARAN BAHASA JEPANG DI SMK NEGERI 5 DENPASAR
}

\author{
N. N. V. Yulianti ${ }^{1}$ N. N. Suartini ${ }^{2}$ I. W. Sadyana ${ }^{3}$ \\ ${ }^{123}$ Jurusan Pendidikan Bahasa Jepang, Universitas Pendidikan Ganesha, Singaraja,Bali \\ e-mail: nyoman.vivin.yulianti@undiksha.ac.id \\ nnsuartini@undiksha.ac.id wayan.sadyana@undiksha.ac.id
}

\begin{abstract}
Penelitian ini bertujuan untuk mendeskripsikan metode yang digunakan guru dalam mengimplementasikan pemahaman lintas budaya dalam pembelajaran bahasa Jepang di SMK Negeri 5 Denpasar dan kendalakendala yang dihadapi guru serta cara mengatasi kendala tersebut. Subjek pada penelitian ini adalah guru bahasa Jepang di SMK Negeri 5 Denpasar dan buku Nihongo Kirakira I. Objek pada penelitian ini adalah metode yang digunakan guru dalam mengimplementasikan pemahaman lintas budaya dalam pembelajaran bahasa Jepang di SMK Negeri 5 Denpasar. Data dikumpulkan melalui metode observasi non partisipatif, wawancara terstruktur dan dokumentasi berupa silabus, RPP dan foto pemahaman lintas budaya, kemudian dianalisis dengan metode deskriptif kualitatif. Hasil penelitian menunjukkan bahwa (1) metode yang digunakan guru dalam mengimplementasikan pemahaman lintas budaya dalam pembelajaran bahasa Jepang di SMK Negeri 5 Denpasar yaitu, grammar translation method, total physical response dan audio lingual method, (2) pada tahap dounyuu, istilah-istilah budaya yang sulit dibandingkan menjadi kendala yang dihadapi guru. Kendala tersebut diatasi dengan memvariasikan media pembelajaran di setiap pertemuan. Pada tahap ouyou renshuu, keterbatasan media seperti yukata dan bahan-bahan masakan Jepang menjadi kendala yang dihadapi guru. Kendala tersebut diatasi guru dengan menerapkan sistem pengelolaan kelas yaitu siswa membentuk kelompok sehingga media dapat di manfaatkan baik oleh siswa.
\end{abstract}

Kata kunci: implementasi, pembelajaran bahasa Jepang, budaya

要旨

本研究の目的は、デンパサール第五国立専門高等学校に日本語勉強の異文化理解に実装する教師の方法 を説明する。また、教える時の問題と解決方法説明する。研究の対象はデンパサール第五国立専門高等 学校の教師と日本語キラキラ1である。研究の対象者はデンパサール第五国立専門高等学校に日本語勉強 の異文化理解に実装する教師の方法である。データー収集は非参加型観察と構造化面接とドキュメンテ ーションはシラバスと教案と異文化理解の写真が入れる。また、本研究は定性的で記述的という研究方 法を利用する。研究の結果は (1) デンパサール第五国立専門高等学校に日本語勉強の方法は, 文法訳読 法、全身反応法、オーディオ・リンガル・アプローチ（AL 法）、（2) 導入の問題は文化の言葉を比較す る。応用練習の問題メディアが足りない。例えば、ゆかたや、日本料理の材料である。教師は教室管理 システムで、この問題を解決する。それはメディアが学生によって使用されることができるように、学 生はグループを形成する。

キーワード : 実残、日本語学習、文化 


\section{Pendahuluan}

Era revolusi industri 4.0 dipercaya akan mendisrupsi banyak bidang salah satunya adalah bahasa asing. Menguasai bahasa asing pada era disrupsi 4.0 sudah menjadi kebutuhan yang sangat diperlukan dalam keterampilan berkomunikasi. Dengan menguasai bahasa asing maka dapat meningkatkan kualitas sumber daya manusia sehingga dapat meningkatkan daya saing seseorang. Bahasa Jepang menjadi salah satu bahasa yang banyak dipelajari oleh masyarakat di berbagai negara. Perkembangan jumlah pembelajar bahasa Jepang di Indonesia mengalami kenaikan yang sangat pesat. Berdasarkan data dari Japan Foundation pada tahun 2015, jumlah pembelajar bahasa Jepang di Indonesia meningkat sekitar $22,2 \%$. Sebagai bahasa asing, bahasa Jepang keberadaannya tidak lepas dari budaya Jepang.

Bahasa merupakan bagian dari kebudayaan. Oleh karena itu, bahasa erat kaitannya dengan budaya. Setiap budaya memiliki ciri khasnya masing-masing sehingga sering kali bertolak belakang. Karena corak budaya yang berbeda, sering kali memiliki persepsi yang berbeda terhadap budaya lain. Persepsi yang berbeda menimbulkan penilaian yang negatif dan cenderung subjektif terhadap tingkah laku, adat kebiasaan, cara berpikir, nilai-nilai serta gagasan orang lain yang berasal dari budaya lain. Hal inilah nantinya dapat menyebabkan kesalahpahaman antara orang-orang yang berbeda budaya. Oleh karena itu, diperlukan pemahaman lintas budaya sehingga perbedaan itu tidak mengakibatkan persoalan atau kesalahpahaman. Pemahaman terhadap budaya orang lain atau budaya suatu masyarakat sangat penting untuk melakukan hubungan, interaksi atau kontak langsung dengan orangorang yang memiliki kebudayaan yang berbeda.

Pembelajaran bahasa dan budaya penting di terapkan dalam dunia pendidikan seperti sekolah-sekolah kejuruan. Salah satu sekolah kejuruan yang menerapkan pembelajaran bahasa dan budaya adalah SMK Negeri 5 Denpasar. SMK Negeri 5 Denpasar merupakan salah satu sekolah kejuruan yang terletak di kota Denpasar. SMK Negeri 5 Denpasar memiliki lima jurusan yang terdiri atas akomodasi perhotelan, tata boga, usaha perjalanan wisata, seni tari dan seni kerawitan. Kedudukan mata pelajaran bahasa Jepang di SMK Negeri 5 Denpasar sebagai mata pelajaran muatan lokal (mulok). Meskipun kedudukan mata pelajaran bahasa Jepang di SMK Negeri 5 Denpasar sebagai mata pelajaran muatan lokal (mulok), tetapi pembelajaran bahasa Jepang sangat penting untuk siswa khususnya untuk siswa SMK ketika terjun dalam dunia pariwisata. Mata pelajaran bahasa Jepang ditawarkan dari kelas X hingga kelas XII di semua jurusan. Buku ajar yang digunakan oleh guru adalah buku Nihongo Kirakira.

Buku Nihongo Kirakira adalah buku yang disusun oleh The Japan Foundation, Jakarta untuk pendidikan bahasa Jepang di tingkat pendidikan menengah di Indonesia. Materi buku disesuaikan dengan silabus yang telah ditetapkan pada kurikulum 2013 revisi 2016. Di akhir setiap bab buku Nihongo Kirakira terdapat budaya Jepang yang ada kaitannya dengan materi pada bab sebelumnya. Budaya tersebut dilengkapi dengan ilustrasi gambar yang jelas sehingga dapat menambah wawasan siswa mengenai budaya. Terdapat 12 jenis budaya yang dipaparkan dalam buku Nihongo Kirakira yaitu, struktur nama, huruf, peringkat siswa SMA, struktur anggota keluarga, hobi, lingkungan sekolah, jadwal pelajaran sekolah, bekal sekolah, hubungan antara guru dan siswa, perlengkapan kelas, seragam sekolah dan kegiatan tahunan sekolah.

Buku Nihongo Kirakira digunakan oleh guru SMK Negeri 5 Denpasar sejak tahun 2017. Buku tersebut digunakan untuk menyesuaikan dengan kurikulum 2013 revisi 2016, juga memperhatikan pendidikan keterampilan hidup di abad ke-21 yaitu, kolaboratif, komunikatif, inovatif dan kreatif. Pembelajaran bahasa Jepang di SMK Negeri 5 Denpasar tidak hanya sebatas pengenalan kosakata dan pola kalimat, tetapi pembelajaran yang juga berfokus pada pengenalan budaya. Hal ini dilihat dari hasil observasi dan wawancara yang telah dilakukan pada hari Kamis, 22 November 2018 bahwa setiap pembelajaran berlangsung, guru selalu menyelipkan perbandingan budaya. Hal tersebut dilakukan untuk memberikan pengetahuan kepada siswa mengenai budaya Jepang dan juga memberikan kesiapan mental kepada siswa SMK ketika berinteraksi di dunia pariwisata. 
Salah satu pengenalan budaya yang dilakukan oleh guru yaitu penggunaan kata sandang san, chan dan kun di Jepang. Guru menjelaskan bahwa kata sandang di Indonesia dengan di Jepang berbeda. Di Indonesia, ketika memanggil nama seseorang, hanya menggunakan nama biasa. Sedangkan di Jepang, penggunaan kata sandang san digunakan untuk panggilan sopan kepada seseorang yang belum dikenal sedangkan chan digunakan untuk panggilan teman pergaulan atau lingkungan keluarga khusus untuk perempuan. Kata sandang kun digunakan untuk panggilan anak laki-laki yang sepantaran atau lebih muda. Penggunaan kata sandang $\sim$ san, $\sim$ chan dan $\sim$ kun diucapkan pada akhir nama seseorang.

Dalam menyampaikan materi, guru tidak hanya terpaku pada buku teks tetapi guru juga menambahkan materi dengan cara bercerita berdasarkan pengalaman pribadi, menampilkan sebuah video dan kartu bergambar. Agar pembelajaran tidak monoton secara teoritikal, guru memberikan contoh kepada siswa terlebih dahulu dengan memanggil nama siswa yang diikuti kata san di belakangnya. Kemudian, guru meminta siswa untuk mempraktekkan dengan teman sebangkunya dengan cara bergantian. Dengan pembelajaran yang sangat bervariatif, maka dapat membangkitkan semangat siswa dan memotivasi siswa untuk mengenal budaya Jepang.

Penelitian mengenai keterkaitan antara bahasa dan budaya sangat menarik untuk diteliti melihat dari penelitian sebelumnya yang dilakukan oleh Nityasari (2017) dengan mengangkat tema konsep perbandingan lintas budaya dalam pembelajaran bahasa Jepang berpendekatan saintifik di SMA Negeri 4 Singaraja. Dalam penelitian ini, data dikumpulkan melalui metode observasi, wawancara dan dokumentasi. Buku yang digunakan oleh guru dalam penelitian ini yaitu, buku Sakura dan buku Nihongo Kirakira. Hasil penelitian ini menunjukkan bahwa penyelipan hal-hal yang berkaitan dengan perbandingan lintas budaya dalam pembelajaran telah membangun tumbuhnya kesadaran dan dapat menambah wawasan siswa terhadap budaya lain sehingga menciptakan siswa yang toleran terhadap perbedaan budaya yang ada. Penelitian ini hanya berfokus pada konsep perbandingan lintas budaya dalam pembelajaran bahasa Jepang dan kendala-kendala yang dihadapi dalam proses mengasosiasi sehingga tidak membahas cara mengatasi kendala-kendala yang dihadapi dalam proses mengasosiasi.

Adapun rumusan masalah dari penelitian ini adalah sebagai berikut.

1. Apakah metode yang digunakan guru dalam mengimplementasikan pemahaman lintas budaya dalam pembelajaran bahasa Jepang di SMK Negeri 5 Denpasar?

2. Bagaimana kendala-kendala yang dihadapi guru serta cara mengatasinya dalam pembelajaran bahasa Jepang di SMK Negeri 5 Denpasar?

Penelitian ini menggunakan beberapa teori yang mendukung proses penelitian. Landasan teori yang digunakan adalah 1) pemahaman budaya, 2) pemahaman lintas budaya, 3) metode pembelajaran bahasa asing, 4) pembelajaran bahasa Jepang dasar dan Buku Nihongo Kirakira I.

Dalam penelitian ini membahas tentang metode yang digunakan guru dalam mengimplementasikan pemahaman lintas budaya dalam pembelajaran bahasa Jepang di SMK Negeri 5 Denpasar. Selain itu, juga dijelaskan kendala-kendala yang dihadapi guru serta cara mengatasi kendala tersebut.

\section{Metode}

\section{Pendekatan dan Jenis Penelitian}

Penelitian ini merupakan penelitian deskriptif kualitatif. Data dalam penelitian ini diperoleh melalui tiga cara yaitu, observasi, wawancara dan dokumentasi. Hasil dari penelitian ini hanya mendeskripsikan atau mengkontruksikan hasil observasi dan wawancara terhadap subjek penelitian sehingga dapat memberikan gambaran yang jelas mengenai metode yang digunakan dalam mengimplementasikan pemahaman lintas budaya dalam pembelajaran bahasa Jepang di SMK Negeri 5 Denpasar. Selanjutnya, pengumpulan data melalui dokumentasi digunakan untuk mendapatkan data yang benar-benar valid. 
Penelitian ini dilakukan pada kelas X Usaha Perjalanan Wisata (UPW) di SMK Negeri 5 Denpasar yang berlokasi di Jalan Ratna no.17, Sumerta Kauh, Denpasar Timur. Pemilihan tempat penelitian ini didasarkan pada pertimbangan bahwa di SMK Negeri 5 Denpasar terdapat pembelajaran bahasa Jepang sesuai dengan kurikulum yang ditetapkan yaitu kurikulum 2013 dan melihat kompetensi guru bahasa Jepang dalam memberikan pemahaman lintas budaya dalam pembelajaran bahasa Jepang.

\section{Sumber Data}

Data yang dikumpulkan dari penelitian ini berasal dari dua sumber yaitu, data primer dan data sekunder. Data primer merupakan data yang diperoleh langsung dari lapangan. Metode pengumpulan data primer dalam penelitian ini dilakukan dengan cara observasi dan wawancara secara langsung dengan satu guru bahasa Jepang di SMK Negeri 5 Denpasar. Sedangkan data sekunder merupakan data berupa dokumen-dokumen. Metode pengumpulan data sekunder dalam penelitian ini dilakukan dengan cara melihat buku ajar yang digunakan oleh guru bahasa Jepang di SMK Negeri 5 Denpasar. Buku ajar yang digunakan yaitu, buku Nihongo Kirakira.

\section{Metode Pengumpulan Data}

Metode pengumpulan data yang digunakan dalam penelitian ini adalah observasi, wawancara terstruktur dan dokumentasi.

Dalam penelitian ini digunakan metode observasi non partisipatif karena hanya dilakukan pengamatan tanpa ikut serta dalam kegiatan. Pengamatan secara langsung dilakukan di kelas X Usaha Perjalanan Wisata (UPW) di SMK Negeri 5 Denpasar untuk memenuhi data yang diperlukan dalam penelitian ini. Observasi dilakukan sebanyak 5 kali dan dilakukan 2 kali dalam seminggu dengan alokasi waktu 4 jam. Observasi dilakukan untuk memperoleh data mengenai, (1) keterkaitan materi dan budaya dalam buku Nihongo Kirakira, (2) melihat budaya yang diperkenalkan dan diimplementasikan oleh guru dalam pembelajaran, (3) melihat kendala-kendala yang dihadapi guru serta melihat respons siswa dalam pembelajaran.

Dalam penelitian ini digunakan wawancara terstruktur. Wawancara dilakukan dengan salah satu guru bahasa Jepang di SMK Negeri 5 Denpasar. Wawancara dilakukan sebanyak 5 kali dengan tujuan untuk melengkapi data hasil observasi yang tidak ditemukan di dalam kelas.

Dalam penelitian ini, metode dokumentasi digunakan untuk memperoleh data yang benarbenar valid dan diperlukan dalam penelitian ini. Kegunaan dari metode dokumentasi adalah untuk mengumpulkan data berupa RPP, silabus, bahan ajar serta foto-foto pembelajaran pemahaman lintas budaya dalam implementasi pembelajaran bahasa Jepang di SMK Negeri 5 Denpasar.

\section{Teknik Analisis Data}

Metode dan teknik analisis data yang digunakan bertujuan untuk mendapatkan gambaran tentang pemahaman lintas budaya dalam implementasi pembelajaran bahasa Jepang di SMK Negeri 5 Denpasar. Teknik analisis yang dilakukan dengan menggunakan beberapa tahap yaitu, 1) reduksi data yakni merangkum atau mencari pokok-pokok penting dari hasil observasi, wawancara dan dokumentasi. Data yang telah diperoleh disederhanakan dan diseleksi relevansinya dengan masalah penelitian, sedangkan data yang tidak diperlukan akan disisihkan, 2) penyajian data yakni data yang sudah direduksi akan disajikan secara kualitatif sesuai dengan rumusan masalah yang dikemukakan, dan 3) menarik kesimpulan atau verifikasi yakni pengambilan intisari dari rangkaian kategori hasil penelitian berdasarkan observasi, wawancara dan dokumentasi mengenai pemahaman lintas budaya dalam implementasi pembelajaran bahasa Jepang di SMK Negeri 5 Denpasar.

\section{Hasil dan Pembahasan}

\section{A. Hasil Penelitian}


Hasil penelitian akan dipaparkan dalam dua hal yaitu, (1) metode yang digunakan dalam mengimplementasikan pemahaman lintas budaya dalam pembelajaran bahasa Jepang dan (2) kendala-kendala yang dihadapi guru serta cara mengatasi kendala-kendala pemahaman lintas budaya dalam pembelajaran bahasa Jepang. Data hasil penelitian dan pembahasan terdiri atas data hasil observasi dan data hasil wawancara sesuai dengan instrumen yang digunakan dalam pengumpulan data.

\section{B. Pembahasan}

Penggunaan buku pedoman sangat penting dalam proses pembelajaran. Dengan adanya buku pedoman maka proses pembelajaran di dalam kelas dapat berlangsung dengan baik. Buku pedoman yang digunakan sebagai acuan dan sumber bahan ajar dalam pembelajaran bahasa Jepang di SMK Negeri 5 Denpasar yaitu, buku Nihongo Kirakira. Buku Nihongo Kirakira diterbitkan oleh Erlangga atas kerjasama dengan The Japan Foundation.

Buku Nihongo Kirakira telah digunakan oleh guru bahasa Jepang di SMK Negeri 5 Denpasar sejak tahun 2017. Isi dari setiap bab dalam buku Nihongo Kirakira terdiri atas keterampilan (can-do) yang artinya kemampuan yang ingin dicapai oleh siswa, pengetahuan (kosakata dan ungkapan), kegiatan (role play/wawancara/presentasi) dan penyelipan budaya yang terletak pada setiap akhir bab yang membahas mengenai perbandingan budaya antara budaya Indonesia dengan budaya Jepang.

Pembelajaran bahasa Jepang di SMK Negeri 5 Denpasar tidak hanya terbatas pada penguasaan kosakata dan pola kalimat saja, akan tetapi guru memfokuskan siswa pada perbandingan budaya antara budaya Indonesia dengan budaya Jepang. Perlunya pemahaman tentang budaya diberikan kepada siswa yaitu, untuk dapat mengetahui seberapa besar pengaruh budaya tersebut dalam mempelajari bahasa khususnya bahasa asing. Memahami pengaruh budaya dalam mempelajari bahasa asing sedikit banyak akan memberikan manfaat baik bagi guru maupun siswa. Jika pengajar dan pembelajar dapat memahami keterkaitan antara bahasa dan budaya maka akan sangat mudah untuk mencapai apa yang menjadi target pengajaran dan pembelajaran (Tjaturrini, 2014).

Proses pembelajaran terbagi menjadi tiga komponen yaitu pendahuluan, inti dan penutup. Pada tahap pendahuluan, guru mengawali pembelajaran dengan mengucapkan salam dalam bahasa Jepang, melakukan absensi dan menyampaikan tujuan pembelajaran. Sebelum memasuki materi yang akan dibahas, guru melakukan pengulangan terhadap materi sebelumnya dengan meminta siswa untuk menerjemahkan kosakata yang diberikan oleh guru. Pada tahap ini, guru menggunakan metode grammar translation method (GTM). Metode ini menekankan pada kemampuan siswa untuk menerjemahkan teks dari bahasa ibu ke bahasa target. Tujuan dari pengajaran dengan menggunakan metode grammar translation method (GTM) adalah agar siswa mampu memahami literatur dalam bahasa target (Padmadewi, 2012). Setelah seluruh siswa ingat dan paham, pembelajaran dilanjutkan dengan materi baru.

Pada tahap inti, guru mengenalkan kosakata kepada siswa melalui media powerpoint. Dalam kegiatan ini, guru memutar audio visual dalam powerpoint, kemudian meminta siswa untuk mendengarkan lalu mengucapkan kembali. Kegiatan tersebut dilakukan oleh siswa secara terus-menerus hingga mencapai pelafalan yang baik dan benar. Dalam memberikan latihan kosakata, guru menggunakan metode audio lingual method. Dalam metode ini, pembelajaran bahasa difokuskan pada lafal kata yang dilakukan berulang-ulang secara intensif (Iskandarwassid dan Sunendar, 2015).

Setelah seluruh siswa paham dengan kosakata yang diberikan, pembelajaran dilanjutkan dengan pengenalan budaya. Pada observasi pertama, ketiga dan kelima, pembelajaran dilakukan secara teoritikal dengan membahas budaya Jepang sedangkan pada observasi kedua, keempat dan kelima, pembelajaran dilakukan secara praktikal dengan melakukan praktek budaya Jepang yang telah dibahas pada pertemuan sebelumnya. Berdasarkan observasi yang telah dilakukan, terdapat 3 budaya yang diperkenalkan kepada siswa yaitu, budaya bekal orang Jepang (obentou), budaya pakaian tradisional Jepang (yukata) dan budaya melipat kertas (origami).

Pada observasi pertama, guru mengenalkan budaya bekal orang Jepang (obentou). Obentou atau bentou adalah istilah bahasa Jepang untuk makanan bekal berupa nasi 
beserta lauk pauk yang dikemas praktis dan bisa dibawa kemana-mana. Sebuah bentou tradisional terdiri dari nasi, ikan atau daging dan sayuran. Meskipun bentou sudah tersedia di banyak tempat di seluruh Jepang, tetapi masih umum untuk ibu rumah tangga di Jepang menghabiskan waktu dan energi membuat bentou untuk pasangan, anak atau diri sendiri (Setyaningsih, 2012).

Guru menjelaskan bahwa di Jepang, menyiapkan bentou sebagai bekal sekolah merupakan hal yang umum untuk dilakukan. Mulai dari tingkatan sekolah dasar hingga pekerja kantoran sekalipun, orang Jepang sering terlihat membawa dan mengonsumsi bentou di jam makan siang. Berbeda dengan orang Indonesia mulai dari tingkatan sekolah dasar hingga pekerja kantoran sekalipun, cenderung jarang membawa dan mengonsumsi bekal di jam makan siang. Orang Indonesia cenderung suka makan di luar atau jajan di luar yang belum terjamin kebersihannya.

Pada saat memberikan perbandingan budaya, guru menggunakan metode ceramah. Dengan metode ceramah, kegiatan belajar peserta didik terutama mendengarkan dengan teliti dan mencatat pokok-pokok penting yang dikemukakan oleh pendidik (Aqib dan Murtadlo, 2016). Metode ceramah digunakan guru untuk memberikan perbandingan budaya antara budaya Indonesia dengan budaya Jepang. Pada saat memberikan perbandingan budaya, guru tidak hanya terpaku pada buku teks, tetapi guru juga menambahkan materi dengan bercerita berdasarkan pengalaman pribadi. Setelah memberikan perbandingan budaya, guru memberikan instruksi kepada siswa bahwa pertemuan selanjutnya akan diadakan praktek membuat masakan Jepang yaitu, takoyaki dan sushi.

Pada observasi kedua, guru dan siswa melakukan praktek membuat masakan Jepang yaitu, takoyaki dan sushi. Takoyaki merupakan makanan tradisional Jepang. Sushi merupakan salah satu makanan khas negara Jepang yang menonjolkan keindahan dan kelezatannya. Kuniko (dalam Theng, dkk, 2015) mengemukakan bahwa sushi menjadi sebuah lambang mengenai tradisi kuno yang berusaha dipertahankan oleh masyarakat Jepang modern ini.

Praktek pengenalan budaya akan dilakukan di luar kelas. Alat-alat dan bahan disiapkan oleh guru dan beberapa juga disiapkan oleh siswa. Sebelum praktek dimulai, guru membagi siswa ke dalam dua kelompok yaitu kelompok takoyaki dan kelompok sushi. Setelah kelompok terbentuk, guru memberikan penjelasan satu persatu kepada setiap kelompok mengenai cara pembuatan takoyaki dan sushi. Selama praktek berlangsung, siswa masih di bawah panduan guru sehingga pada saat siswa memiliki kendala, guru bisa mengatasi dengan memberikan penjelasan yang lebih detail lagi. Dari awal praktek hingga praktek usai dilakukan, seluruh siswa sangat terlihat bersemangat dan antusias sehingga praktek dapat berjalan dengan baik.

Pada observasi ketiga, guru membahas mengenai seragam sekolah di Jepang. Orang Jepang sering mengenakan seragam sekolah saat sekolah dasar, sekolah menengah pertama dan sekolah menengah atas. Salah satu aspek penting dalam seragam sekolah di Jepang adalah model yang berubah sesuai dengan musim. Siswa memiliki seragam sekolah versi musim panas dan versi musim dingin untuk mengatasi perubahan cuaca yang sering terjadi di Jepang (Asano, 2014). Guru menjelaskan bahwa seragam sekolah di Jepang dengan di Indonesia sangat berbeda. Seragam sekolah di Jepang hanya terdapat satu jenis yang dapat dipakai setiap hari, sedangkan seragam sekolah di Indonesia ada beberapa jenis sesuai dengan hari-hari tertentu.

Selain itu, guru juga menjelaskan bahwa untuk mengetahui tingkatan siswa di Jepang dengan di Indonesia berbeda. Tingkatan siswa di Jepang dilihat dari corak warna sepatu yang dipakai oleh siswa, sedangkan tingkatan siswa di Indonesia dilihat dari simbol garis dasi yang digunakan oleh siswa. Setelah memberikan penjelasan mengenai seragam sekolah, guru memberikan instruksi kepada siswa bahwa pertemuan selanjutnya akan diadakan praktek penggunaan yukata. Yukata akan di sediakan oleh guru dan selama praktek akan di pandu oleh guru.

Pada observasi keempat, siswa melakukan praktek penggunaan yukata. Guru menjelaskan bahwa yukata dan kimono merupakan pakaian tradisional Jepang yang berbeda. Yukata termasuk dalam kimono non formal yang biasa dipakai pada saat musim 
panas. Yukata digunakan pada saat suasana santai, melihat pesta kembang api, melihat festival musim panas (natsu matsuri) dan juga untuk menari pada saat perayaan obon. Sedangkan kimono hanya dipakai untuk menghadiri acara formal saja.

Setelah memberikan penjelasan mengenai yukata, guru melanjutkan pembelajaran dengan meminta siswa untuk membentuk 7 kelompok. Karena keterbatasan yukata yang dimiliki oleh guru, maka siswa melakukannya secara berkelompok sehingga semua siswa dapat melakukannya secara bergantian. Sebelum siswa melakukan praktek, guru terlebih dahulu memberikan contoh penggunaan yukata dan memberikan penjelasan langkahlangkah penggunaan yukata yang benar. Selama praktek berlangsung, banyak kesalahankesalahan yang dilakukan oleh siswa, tetapi kesalahan-kesalahan tersebut tidak mengurangi rasa semangat siswa dalam mengenal budaya Jepang. Kesalahan yang dilakukan siswa, diatasi oleh guru dengan memberikan penjelasan yang lebih detail.

Pada observasi kelima, akan dilakukan pemberian materi tentang kemahiran dan juga praktek mengenai budaya melipat kertas (origamı). Guru mengawali pembelajaran dengan melakukan perbandingan mengenai kegiatan ekstra kurikuler di Jepang dengan di Indonesia. Guru menjelaskan bahwa siswa di Jepang sangat antusias dengan kegiatan ekstra kurikuler. Karena dengan adanya kegiatan ekstra kurikuler, maka siswa di Jepang dapat melatih kemahirannya melalui kegiatan ekstra kurikuler tersebut. Tidak kalah berbeda dengan di Jepang, di Indonesia juga terdapat kegiatan ekstra kurikuler yang dapat mengasah kemampuan siswa dalam bidang-bidang tertentu. Setelah pemberian materi selesai, guru mengajak siswa untuk melakukan praktek membuat origami. Praktek dilakukan dalam satu pertemuan karena membuat origami tidak begitu banyak menghabiskan waktu.

Guru menjelaskan bahwa praktek hari ini akan membuat origami senba zuru. Origami berasal dari kata ori yang berarti lipat dan kami yang berarti kertas. Origami merupakan suatu kesenian melipat kertas. Guru menjelaskan bahwa senba zuru memiliki arti kumpulan seribu origami burung bangau. Hal ini dilatar belakangi oleh kepercayaan rakyat Jepang bahwa bangau adalah salah satu makhluk suci dari dua makhluk suci lainnya yaitu naga dan kura-kura. Seribu bangau kertas menjadi simbol perdamaian dunia.

Setelah memberikan penjelasan arti origami senba zuru, guru melanjutkan dengan membagikan kertas origami kepada siswa. Kemudian, memberikan instruksi kepada siswa mengenai langkah-langkah pembuatan origami senba zuru. Pada langkah awal pembuatan origami senba zuru, siswa dapat mengikuti instruksi guru dengan baik. Tetapi, siswa mengalami sedikit kendala pada tahap pembuatan kepala burung bangau. Kendala tersebut diatasi guru dengan memberikan penjelasan kembali sehingga siswa dapat mengikuti dan menyelesaikan origami senba zuru dengan baik dan benar.

Dalam tahap praktek, guru menggunakan metode Total Physical Response (TPR). Potensi utama menggunakan Total Physical Response (TPR) dalam pengajaran bahasa adalah menciptakan kondisi yang mirip dengan pembelajaran bahasa utama (membuat input bermakna dan dapat dipahami), melibatkan anak-anak secara efektif dan dalam membantu melalui gerakan motorik (Savic, 2014). Metode Total Physical Response (TPR) digunakan oleh guru agar siswa dapat terlibat langsung dalam penggunaan media dan pengenalan budaya Jepang.

Pada tahap penutup, guru menutup pembelajaran dengan bertanya kepada siswa mengenai hal yang belum dipahami selama proses pembelajaran maupun selama praktek. Kemudian, guru meminta siswa untuk menyimpulkan pembelajaran dan mengakhiri pertemuan dengan mengucapkan salam dalam bahasa Jepang.

Mempelajari budaya suatu bangsa tidak hanya dengan mempelajari bahasanya, tetapi juga bisa dilakukan dengan mengenal budaya, kesenian dan sebagainya. Dengan memberikan pengenalan budaya Jepang kepada siswa akan menimbulkan minat dan ketertarikan siswa untuk mempelajari lebih banyak budaya Jepang. Selain itu, pentingnya pengenalan budaya di terapkan dalam proses pembelajaran karena dapat mengurangi dampak gegar budaya (culture shock) dan dapat meningkatkan kemampuan mengenai perbedaan antar budaya serta kemampuan belajar hidup bersama ditengah perbedaan.

Berdasarkan pemaparan di atas dapat disimpulkan bahwa metode yang digunakan guru dalam implementasi pemahaman lintas budaya dalam pembelajaran bahasa Jepang yaitu, 
grammar translation method (GTM), total physical response (TPR), audio lingual method dan metode ceramah. Kemudian, dapat disimpulkan bahwa alur pembelajaran bahasa Jepang di SMK Negeri 5 Denpasar dapat dikategorikan menjadi 3 tahapan yang terdiri atas tahap dounyuu, kihon renshuu dan ouyou renshuu.

Tahap dounyuu terletak pada awal pembelajaran. Guru mengawali pembelajaran dengan menampilkan sebuah gambar melalui media powerpoint. Gambar tersebut berkaitan dengan tema budaya yang akan dibahas. Pada tahap ini, guru memberikan pemahaman kepada siswa mengenai budaya Jepang sekaligus memberikan perbandingan antara budaya Indonesia dengan budaya Jepang.

Tahap kihon renshuu terletak pada inti pembelajaran. Setelah memberikan pemahaman tentang budaya, guru memberikan kosakata yang berkaitan dengan budaya. Pada tahap ini, guru memutar audio visual dalam powerpoint dan meminta siswa untuk mendengarkan lalu mengucapkan secara berulang-ulang hingga mendapatkan pelafalan yang baik.

Tahap ouyou renshuu terletak pada akhir pembelajaran. Pada tahap ini, guru dan siswa melakukan praktek pengenalan budaya sesuai dengan materi yang sudah di bahas pada pertemuan sebelumnya. Adapun pengenalan budaya yang diberikan oleh guru yaitu, budaya "bekal orang Jepang (obentou), budaya "pakaian tradisional Jepang (yukata)" dan budaya "melipat kertas (origami).

Adapun kendala-kendala yang dihadapi guru serta cara mengatasi kendala tersebut yaitu, (1) Pada tahap dounyuu, kendala yang dihadapi guru yaitu terdapat istilah-istilah budaya yang sulit dibandingkan. Kendala tersebut diatasi guru dengan menggunakan media pembelajaran berupa powerpoint di setiap pertemuan, dan (2) Pada tahap ouyou renshuu, kendala yang dihadapi guru yaitu keterbatasan media seperti yukata dan bahan-bahan masakan Jepang. Kendala tersebut diatasi guru dengan menerapkan sistem pengelolaan kelas. Guru meminta siswa untuk membentuk kelompok pada saat praktek sehingga media dapat dimanfaatkan dengan baik oleh seluruh siswa.

\section{Simpulan dan Saran}

\section{A. SIMPULAN}

1. Pembelajaran bahasa Jepang di SMK Negeri 5 Denpasar dapat di kategorikan ke dalam 3 tahapan yaitu, ouyou renshuu, kihon renshuu dan ouyou renshuu. Tahap dounyuu terletak pada awal pembelajaran. Guru mengawali pembelajaran dengan menampilkan sebuah gambar melalui media powerpoint. Gambar tersebut berkaitan dengan tema budaya yang akan di bahas. Pada tahap ini, guru memberikan pemahaman kepada siswa mengenai budaya Jepang sekaligus memberikan perbandingan antara budaya Indonesia dengan budaya Jepang. Tahap kihon renshuu terletak pada inti pembelajaran. Setelah memberikan pemahaman tentang budaya, guru memberikan kosakata yang berkaitan dengan budaya. Pada tahap ini, guru memutar audio visual dalam powerpoint dan meminta siswa untuk mendengarkan lalu mengucapkan secara berulang-ulang hingga mendapatkan pelafalan yang baik. Tahap ouyou renshuu terletak pada akhir pembelajaran. Pada tahap ini, guru dan siswa melakukan praktek pengenalan budaya sesuai dengan materi yang sudah di bahas pada pertemuan sebelumnya.

2. Kendala-kendala yang dihadapi guru pada tahap dounyuu yaitu terdapat istilah-istilah budaya yang sulit dibandingkan. Kendala tersebut diatasi guru dengan memvariasikan media pembelajaran di setiap pertemuan. Sedangkan pada tahap ouyou renshuu, kendala yang dihadapi guru yaitu keterbatasan media seperti yukata dan bahan-bahan masakan Jepang. Kendala tersebut diatasi guru dengan menerapkan sistem pengelolaan kelas. Guru meminta siswa untuk membentuk kelompok pada saat praktek sehingga media dapat di manfaatkan dengan baik oleh seluruh siswa.

\section{B. SARAN}

1. Kepada guru bahasa Jepang di SMK Negeri 5 Denpasar disarankan lebih meningkatkan kreativitas dalam pembelajaran dengan menerapkan berbagai metode dan memvariasikan media pembelajaran sehingga pembelajaran bahasa Jepang 
khususnya dalam pembelajaran budaya lebih menarik dan dapat memotivasi siswa dalam mempelajari budaya Jepang.

2. Kepada peneliti lain disarankan untuk meningkatkan terhadap penelitian sejenis agar dapat dimanfaatkan sebagai acuan dalam memahami implementasi pemahaman lintas budaya khususnya dalam pembelajaran bahasa Jepang.

\section{Daftar Pustaka}

Aqib, Zainal dan Murtadlo, Ali. 2016. Kumpulan Metode Pembelajaran. Bandung: PT Sarana Tutorial Nurani Sejahtera.

Asano, Vie. 2014. "Mengenal Lebih Dekat Seragam Sekolah di Jepang". Tersedia pada https://japanesestation.com/mengenal-lebih-dekat-seragam-sekolah-di-jepang (diakses pada 11 Mei 2019).

Iskandarwassid dan Sunendar. 2015. Strategi Pembelajaran Bahasa. Bandung: PT Remaja Rosdakarya Offset.

Nityasari, Made Elisa. 2017. Konsep Perbandingan Lintas Budaya Dalam Pembelajaran Bahasa Jepang Berpendekatan Saintifik di SMA Negeri 4 Singaraja. Skripsi (tidak diterbitkan) Fakultas Bahasa dan Seni, Universitas Pendidikan Ganesha.

Padmadewi, Ni Nyoman. 2012. Strategi Pembelajaran Bahasa. Undiksha Press.

Savic, Vera. 2014. "Total Physical Responser (TPR) Activities in Teaching English to Young Learnes". Tersedia pada https://www.researchgate.net/publication/307583559 TOTAL PHYSICAL RESPO NSE TPR ACTIVITIES IN TEACHING ENGLISH TO YOUNG LEARNERS (diakses tanggal 9 Februari 2019).

Setyaningsih, Sri. 2011. "Seni Menata

Bento". Tersedia pada https://lib.unnes.ac.id/7927/1/10299.pdf (diakses tanggal 9 Mei 2019).

The Japan Foundation. 2017. "Survey Report on Japanese Language Education Abroad 2015". Tersedia pada https://www.jpf.go.jp/e/project/japanese/survey/result/survey15.html (diakses tanggal 4 April 2019).

Theng, dkk. 2015. "Nilai Estetika dan Cita Rasa Makanan dalam Penyajian Makizushi Musim Gugur Pada TV Champion Jepang". Tersedia pada http://eprints.dinus.ac.id/17734/1/jurnal 15342.pd (diakses tanggal 9 Mei 2019).

Tjaturrini, Dyah. 2014. "Pengaruh Budaya Dalam Pembelajaran Bahasa (Asing)". Tersedia pada http://eprints.undip.ac.id/54567/ (diakses tanggal 22 Maret 2019). 